\title{
The Use of Autoradiography to Determine the Proportion of Bacteria Metabolizing in an Aquatic Habitat
}

\author{
By ANGELA J. RAMSAY* \\ Department of Botany, University of Canterbury, Christchurch, New Zealand
}

(Received I6 April I973; revised I2 July 1973)

\begin{abstract}
SUMMARY
Autoradiographic methods have been developed to determine the proportion of metabolizing bacteria on leaves of Elodea canadensis. Detection with a light microscope of tritium labelling of pure cultures of bacteria was optimal when samples were incubated with $20 \mu \mathrm{Ci}$ of $\left[{ }^{3} \mathrm{H}\right]$ glucose or $\left[{ }^{3} \mathrm{H}\right]$ thymidine $/ \mathrm{ml}$ for $\mathrm{r} \cdot 75$ to $2 \mathrm{~h}$ and the bacteria exposed to $\mathrm{K}_{2}$ emulsion for $\mathrm{I} 4$ days. Two fluorescent pseudomonads did not form autoradiograms when labelled with $\left[{ }^{3} \mathrm{H}\right]$ thymidine. For autoradiograms of bacteria from $E$. canadensis, $\mathrm{L}_{4}$ emulsion was more suitable than $\mathrm{K}_{2}$ emulsion.

High-resolution autoradiograms were prepared of a pure culture of a pseudomonad and of bacteria from moribund leaves of Elodea canadensis. Counts of labelled and unlabelled cells in light-microscopic and high-resolution autoradiograms suggested that valid counts of labelled bacteria could be obtained from light-microscopic autoradiograms. Direct counts of bacteria from $E$. canadensis leaves of different ages revealed greater increases as leaves matured and died than did indirect methods. Autoradiographic data from young leaves indicated that the percentage of bacteria labelled with $\left[{ }^{3} \mathrm{H}\right]$ glucose was similar to the percentage of the total population which was estimated by the plate method. On the mature and moribund leaves larger proportions of the populations were labelled with $\left[{ }^{3} \mathrm{H}\right] \mathrm{glucose}$ than were included in the plate counts.
\end{abstract}

\section{INTRODUCTION}

Ecological studies of micro-organisms are frequently limited by the difficulty of relating numbers of organisms to the activity of the population (Jannasch, I965). One technique which can be used to study the uptake of substrates by individual cells is autoradiography. Brock \& Brock (I968), Munro \& Brock (I968) and Paerl \& Goldman (I972) have detected metabolizing bacteria in aquatic environments by this method. Waid, Preston \& Harris (197I) have described autoradiographic procedures to detect metabolically active fungal hyphae in leaf-litter habitats.

Quantitative data can be obtained from autoradiograms by counting the proportions of labelled and unlabelled cells (Brock \& Brock, 1968). However, if such a count is to be a direct measure of the metabolic activity of the population, certain conditions must be satisfied. The labelled substrate must be a metabolite which can be assimilated by the majority of bacteria. The sample must be labelled with a sufficiently high concentration of isotope and for long enough for all metabolizing bacteria to accumulate enough isotope to form an autoradiogram, but the sample must not be incubated with the label for so long that inactive bacteria begin to grow.

In the present study autoradiography was used to determine the proportions of metabolizing bacteria in populations from the pond weed Elodea canadensis sampled from a lake.

* Present address: Department of Applied Biology, University of Wales Institute of Science and Technology, Cathays Park, Cardiff, Wales. 
Preliminary experiments were carried out with pure cultures of bacteria to determine the optimum conditions for autoradiography of tritium-labelled bacteria, such that all bacteria metabolizing at the time of sampling would be detected. Most of the autoradiograms were prepared for the light microscope (LM), but some methods of preparing autoradiograms for an electron microscope (EM) were investigated. Counts of labelled bacteria from LM and EM autoradiograms of similar material were compared. Relationships between the proportions of metabolizing bacteria on leaves of Elodea canadensis, determined by lightmicroscopic autoradiography, and direct and indirect counts of the bacterial population were investigated.

\section{Pure-culture experiments}

\section{METHODS}

The following bacteria from the Botany Department Culture Collection, Canterbury University (B.D.C.C.) or isolated from a freshwater lake (L.G.) were used: Escherichia coli, B.D.C.C. no. B 22; Pseudomonas fluorescens, B.D.C.C. no. B 5; fluorescent pseudomonad, L.G. no. 6D3 7; non-fluorescent pseudomonad, L.G. no. 6w 5; Cytophaga spp., L.G. nos. I and 2.

The following isotopes were obtained from the Radiochemical Centre, Amersham, Buckinghamshire: $\left[{ }^{\mathrm{I}}{ }^{3} \mathrm{H}\right] \mathrm{D}$-glucose $(792 \mathrm{mCi} / \mathrm{mmol}$ used to prepare isotope concentrations of $10 \mu \mathrm{Ci} / \mathrm{ml}$ and less, and $250 \mathrm{mCi} / \mathrm{mmol}$ for concentrations of 17 and $20 \mu \mathrm{Ci} / \mathrm{ml}$ ); and [methyl- ${ }^{3} \mathrm{H}$ ] thymidine $(17.4 \mathrm{Ci} / \mathrm{mmol}$ for concentrations of $10 \mu \mathrm{Ci} / \mathrm{ml}$ and less, and $19.5 \mathrm{Ci} / \mathrm{mmol}$ for concentrations of 17 and $20 \mu \mathrm{Ci} / \mathrm{ml}$ ). Isotope solutions were diluted aseptically with sterile distilled water.

Bacteria were labelled by adding 0.5 to $\mathrm{I} \mathrm{ml}$ broth culture (nutrient broth, Oxoid CMI, or Cytophaga medium described by Anderson \& Ordal in 196I) which had been incubated for 18 to $24 \mathrm{~h}$ to an equal volume of diluted isotope solution in a bijou bottle. In one experiment bacteria from a nutrient agar slant were labelled. The final concentration of isotope was between I and $20 \mu \mathrm{Ci} / \mathrm{ml}$.

After incubating for I to $2 \mathrm{~h}$ at room temperature, bacteria were fixed with Lugol's iodine or, in one experiment, $3 \%$ glutaraldehyde in phosphate buffer ( $\mathrm{pH} 7$ ).

Smears of bacteria were made at one end of microscope slides which had been subcultured with gelatin (Gude, I968). After heat fixing the smears were washed in a beaker of running water for $30 \mathrm{~s}$.

Ilford liquid nuclear emulsions, $\mathrm{K}_{2}$ or $\mathrm{L}_{4}$, were used to prepare the autoradiograms. The method of diluting both emulsions was the same. The emulsion was put in a flattened test-tube (Gude, I968) and melted in the darkroom at $43{ }^{\circ} \mathrm{C}$ for I h. It was then diluted with an equal volume of distilled water heated to $43{ }^{\circ} \mathrm{C}$. Slides were dipped singly and the emulsion wiped off the back. They were placed on a cold steel strip until the emulsion had gelled (Rogers, 1967) and then put in a glass slide rack. These racks were placed with a silica-gel bag in a light-proof jar. The slides were left at room temperature for $2 \mathrm{~h}$ and then exposed in the jars at $4{ }^{\circ} \mathrm{C}$ for 3 to $\mathrm{I} 4$ days. Photographic processing was carried out at $20^{\circ} \mathrm{C}$, as follows:

K2

$\begin{array}{ll}\text { Developer } & \text { ID-I I (IO min) } \\ \text { Stop } & \text { Tap water (IO s) } \\ \text { Fixative } & \text { 20\% (w/v) Sodium } \\ & \text { thiosulphate }(7 \mathrm{~min}) \\ \text { Wash } & \text { Tap water changed } 5 \text { times } \\ & \text { over I } 2 \text { min }\end{array}$

$\mathrm{L}_{4}$

ID-2 diluted I : 1 (4 min)

I \% acetic acid (IO s)

May and Baker Super

Amfix I : 6 (5 min)

Tap water changed 5 times over $10 \mathrm{~min}$ 
The slides were air dried, stained with $0.3 \%$ aqueous methylene blue for $30 \mathrm{~s}$ and examined by means of bright field optics. Immersion oil was placed directly on the film, and bacteria, within areas outlined by a rectangle in the eyepiece, were scored as labelled or unlabelled. No attempt was made to count individual silver grains. The number of bacteria to be examined, for an allowable error of $5 \%$ within confidence limits of $95 \%$, was calculated by assuming the sample was distributed binomially on the slide. The percentage of labelled bacteria was then calculated. Replicate counts from three areas of the slide were made for three of the treatments. A single count was made of the remaining autoradiograms.

The effects of varying the following factors on the detection of labelled bacteria by autoradiography were examined: (i) isotope concentration, (ii) time of incubation of the sample with the isotope, and (iii) time the emulsion was exposed to the isotope. A single autoradiogram was prepared for each treatment. Controls in which bacteria were fixed before labelling, and blank slides to assess the background level of grains, were included in each experiment.

\section{Preparation of field material for light microscopic autoradiography}

Samples of Elodea canadensis were obtained from Lake Grasmere, a freshwater lake situated in inland Canterbury, New Zealand. Leaves were detached from the stem and labelled in groups of up to Io in bijou bottles. They were incubated for $\mathrm{I} \cdot 75$ to $2 \mathrm{~h}$ with $20 \mu \mathrm{Ci} / \mathrm{ml}$ of isotope and then fixed with Lugol's iodine. One sample of moribund leaves was fixed with $3 \%$ glutaraldehyde in phosphate buffer $(\mathrm{pH} 7)$. The bacteria were then scraped from 2 to 3 leaves with a small piece of metal on to a glass slide. The suspension was transferred to a $2.5 \mathrm{ml}$ centrifuge tube for washing before a smear was made.

Autoradiograms of the smears of bacteria were prepared as described for pure cultures of bacteria. They were exposed for I 3 to I 4 days. After photographic processing, smears were stained for $5 \mathrm{~min}$ in methylene blue. When dry, the autoradiograms were permanently mounted by using a modification of Bélanger's method (I96I). Cedarwood oil was placed on the film for 45 min to clear the algae. The oil was drained off and I: I DePex (G. T. Gurr Ltd, High Wycombe, Buckinghamshire) and xylol applied for $20 \mathrm{~min}$. The autoradiogram was then mounted under a coverslip in DePex: xylol (3:I v/v).

\section{High-resolution autoradiography}

Preparations of negatively stained bacteria with and without an emulsion layer over them were examined to determine the extent of loss of resolution when emulsion was placed over unsectioned bacteria.

Autoradiograms of pseudomonad 6w 5 and bacteria from moribund leaves of Elodea canadensis were prepared for the EM. Samples were incubated for $\mathrm{I} \cdot 75$ to $2 \mathrm{~h}$ with $20 \mu \mathrm{Ci} / \mathrm{ml}$ of isotope. The fixative was $3 \%$ glutaraldehyde in phosphate buffer $(\mathrm{pH} 7)$. After labelling, bacteria were negatively stained with $2 \%(\mathrm{w} / \mathrm{v})$ phosphotungstic acid (Horne, 1965). The pure culture was concentrated by centrifuging before staining. Bacteria from the leaf samples were stained after they had been scraped from the leaves as described above and washed by two cycles of centrifuging and resuspending. Staining was usually for 7 to $8 \mathrm{~min}$ but was extended to 3 to $4 \mathrm{~h}$ in some instances. The stained bacteria were applied to carbon-coated collodion grids by touching a one-hole grid on to the suspension and lowering this on to the grid. The suspension was immediately dried down on to the grid with a corner of filter paper.

The looping method of Caro \& van Tubergen (1962) was used with some modifications 
to apply Ilford $\mathrm{L}_{4}$ emulsion to the grids. The emulsion was melted and diluted with three times its volume of distilled water. The diluted emulsion was poured into a Petri dish and kept at about $40^{\circ} \mathrm{C}$. With a platinum/palladium loop, $4.5 \mathrm{~cm}$ in diameter, a film was picked up and allowed to dry with continual rotation of the loop. When the emulsion was just beginning to gel, it was touched down on to a grid, which was on a brass stub $3 \mathrm{~mm}$ in diameter.

The emulsion-coated grids were attached by the edge with tape to glass slides. They were exposed in a light-proof jar in an atmosphere of nitrogen. Grids of the pseudomonad were exposed for 28 and 56 days and the $\left[{ }^{3} \mathrm{H}\right]$ thymidine-labelled bacteria from Elodea canadensis for 28,56 and 84 days, with 3 grids for each treatment. Two grids of $\left[{ }^{3} \mathrm{H}\right]$ glucose-labelled bacteria from the leaves were exposed for 84 days only. Controls of bacteria from leaves fixed before labelling with $\left[{ }^{3} \mathrm{H}\right]$ thymidine and $\left[{ }^{3} \mathrm{H}\right]$ glucose were set up in triplicate and examined after 84 days. A blank grid was included for each exposure period to check the background level of grains.

After exposure the slides with grids attached were processed as described by Caro \& van Tubergen (1962). The grids were examined with a Hitachi HS-7 microscope and the numbers of labelled and unlabelled bacteria recorded. A single composite count for each treatment was made from the replicate grids.

\section{Comparison of percentage of labelled bacteria in LM and EM autoradiograms}

LM and EM autoradiograms of pseudomonad $6 \mathrm{w} 5$ and bacteria from moribund leaves sampled in winter (June) were prepared. All samples were fixed with glutaraldehyde and $\mathrm{L}_{4}$ emulsion was used.

Relationship between direct and indirect counts of bacteria and proportions of metabolizing bacteria determined by autoradiography

The bacterial populations of Elodea canadensis leaves of different ages, sampled in winter (July), were studied. Three categories of leaves were distinguished: young leaves within $\mathrm{I}$ to $3 \mathrm{~cm}$ of the shoot tip; mature green leaves; and brown, moribund, but still entire leaves further down the stem. The numbers of bacteria on ten leaves in each of these categories were estimated by the pour-plate method. Leaves were comminuted (Measuring and Scientific Equipment Ltd, London, homogenizer) in a $10 \mathrm{ml}$ distilledwater blank and dilutions were plated on nutrient agar (Oxoid CMI) with five replicates. Plates were incubated at $20{ }^{\circ} \mathrm{C}$ for I 4 days. The number of bacteria/mm² of leaf surface was calculated.

Bacteria were counted directly by comminuting 2 or 3 leaves which had been fixed in Lugol's iodine. The leaf suspension was diluted and filtered through a filter (poresize, $0.45 \mu \mathrm{m}$; Millipore Filter Corp., Bedford, Massachusetts, U.S.A.) for counting. The filter was stained with $0.3 \%$ aqueous methylene blue and, when dry, cleared with dimethyl sulphoxide in isopropanol as described in Bulletin 22Ic (Gelman Instrument Co., Ann Arbor, Michigan, U.S.A.).

\section{RESULTS}

\section{Pure-culture experiments}

No labelled bacteria were seen on any of the control autoradiograms of bacteria fixed before labelling. No uptake of isotope was detected when bacteria were labelled with I $\mu \mathrm{Ci} / \mathrm{ml}$ of $\left[{ }^{3} \mathrm{H}\right]$ glucose for $\mathrm{I} \mathrm{h}$ and autoradiograms were exposed for 3 to 4 days.

Fig. I shows the effect of higher concentrations of isotope and different incubation and 


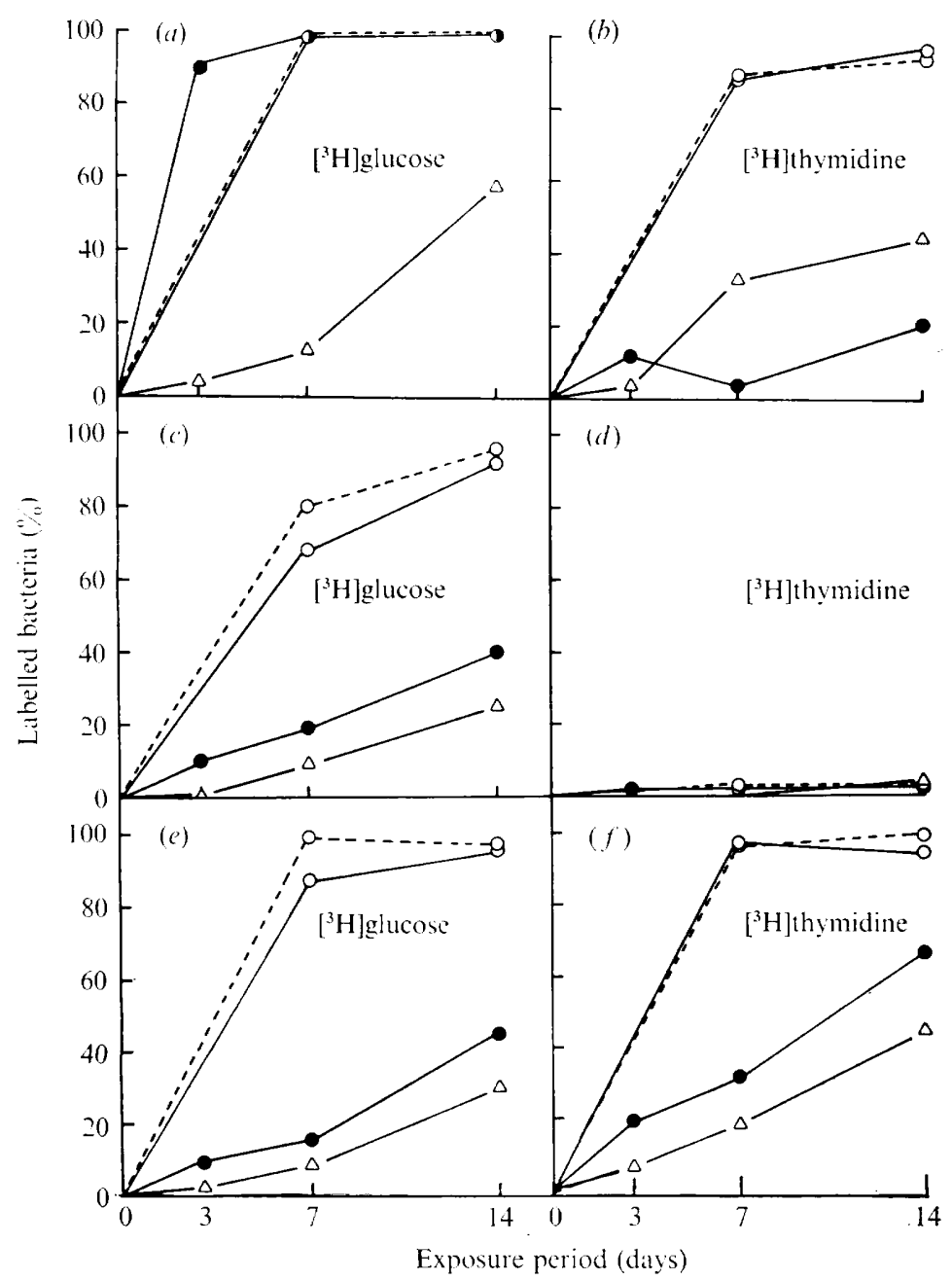

Fig. I. The effect of different incubation and exposure periods, and concentrations of isotope, on the percentage of labelled bacteria detected by autoradiography. $\Delta, 5 \mu \mathrm{Ci} / \mathrm{ml} ; 0,10 \mu \mathrm{Ci} / \mathrm{ml} ; \bigcirc, 20 \mu \mathrm{Ci} /$ $\mathrm{ml} ;-, \mathrm{I}$ h incubation; ------, 2 h incubation. $(a)$ and $(b)$, Escherichia coli; $(c)$ and $(d)$, Pseudomonas fluorescens; $(e)$ and $(f)$, Cytophaga spp.-for isotope concentrations of 5 and $10 \mu \mathrm{Ci} / \mathrm{ml}$ Cytophaga no. I was used, for $20 \mu \mathrm{Ci} / \mathrm{ml}$ isotope Cytophaga no. 2 was used.

exposure periods on the percentage of labelled bacteria detected by autoradiography. The percentage of labelled bacteria has been plotted against increasing exposure time. Each point represents a single count from one autoradiogram. For the three slides where replicate counts were carried out the standard deviations of the counts were very small, examples of the percentage of labelled bacteria being $92 \pm \mathrm{I}, 3 \mathrm{I} \pm 2$, and $58 \pm 2$. With 5 and $10 \mu \mathrm{Ci} / \mathrm{ml}$ of both isotopes, an increasing number of bacteria had silver grains over them with the extension of exposure time but, except for the labelling of Escherichia coli with [ $\left.{ }^{3} \mathrm{H}\right]$ glucose (Io $\mu \mathrm{Ci} / \mathrm{ml}$ ), $20 \mu \mathrm{Ci} / \mathrm{ml}$ of both compounds and I4 days' exposure were needed to ensure that all metabolically active bacteria were detected.

The results of labelling pseudomonad $6 \mathrm{w} 5$ with $\left[{ }^{3} \mathrm{H}\right]$ thymidine are shown in Table $\mathrm{I}$. When an isotope concentration of $17 \mu \mathrm{Ci} / \mathrm{ml}$ was combined with $1 \cdot 75 \mathrm{~h}$ incubation and 
Table I. Detection of uptake of $\left[{ }^{3} \mathrm{H}\right] \mathrm{glucose}$ and $\left[{ }^{3} \mathrm{H}\right]$ thymidine by two pseudomonads

\begin{tabular}{|c|c|c|c|c|c|}
\hline Isolate* & $\begin{array}{l}\text { Labelled } \\
\text { substrate }\end{array}$ & $\begin{array}{l}\text { Concentration } \\
\text { of isotope } \\
(\mu \mathrm{Ci} / \mathrm{ml})\end{array}$ & $\begin{array}{l}\text { Incubation } \\
\text { period } \\
\text { (h) }\end{array}$ & $\begin{array}{l}\text { Exposure } \\
\text { period } \\
\text { (days) }\end{array}$ & $\begin{array}{c}\text { Bacteria } \\
\text { labelled } \\
(\%)\end{array}$ \\
\hline Pseudomonad 6w 5 & Glc & 17 & $I \cdot 75$ & 7 & 94 \\
\hline Pseudomonad 6w 5 & Glc & 17 & $\mathrm{I} \cdot 75$ & 3 & $90 \dagger$ \\
\hline Pseudomonad 6w 5 & Glc & 20 & 2 & 7 & $92 \div$ \\
\hline Pseudomonad 6w 5 & $\mathrm{Tdr}$ & 17 & $\mathrm{I} \cdot 75$ & 7 & 63 \\
\hline Pseudomonad 6D3 7 & Glc & 17 & $I \cdot 75$ & 7 & 66 \\
\hline Pseudomonad 6D37 & $\mathrm{Tdr}$ & 17 & $x \cdot 75$ & 7 & 7 \\
\hline
\end{tabular}

7 days' exposure, not all bacteria capable of metabolizing the substrate formed an autoradiogram. The labelling of the fluorescent pseudomonad $6 \mathrm{D} 37$ with $\left[{ }^{3} \mathrm{H}\right]$ glucose (Table I) can be compared with the higher percentage of labelled bacteria in the autoradiogram of Pseudomonas fluorescens labelled with $\left[{ }^{3} \mathrm{H}\right] \mathrm{glucose},(20 \mu \mathrm{Ci} / \mathrm{ml})$, incubated for $2 \mathrm{~h}$ and exposed for 7 days (Fig. I). For both fluorescent pseudomonad isolates, uptake of $\left[{ }^{3} \mathrm{H}\right]$ thymidine was almost undetectable (Fig. I; Table I).

The optimum conditions for detection of tritium labelling with $\mathrm{K} 2$ emulsion were therefore an isotope concentration of $20 \mu \mathrm{Ci} / \mathrm{ml}$, an incubation period of bacteria with the isotope of $\mathrm{I} \cdot 75$ to $2 \mathrm{~h}$ and an exposure of the emulsion to radiation for $\mathrm{I} 4$ days.

Autoradiograms of pseudomonad $6 \mathrm{w} 5$, labelled with $\left[{ }^{3} \mathrm{H}\right] \mathrm{glucose}$, were prepared with $\mathrm{L}_{4}$ emulsion after glutaraldehyde fixation as well as with $\mathrm{K}_{2}$ emulsion after iodine fixation. After exposure for 3 days, $90 \%$ of the bacteria had formed an autoradiogram with $\mathrm{L}_{4}$ emulsion while $94 \%$ had silver grains over them after exposure for 7 days to $\mathrm{K} 2$ emulsion (Table I). Varying the fixative also did not affect the percentage of labelled bacteria in the autoradiograms.

\section{Light-microscopic autoradiography with field material}

Thorough washing of the sample after labelling followed by concentration by centrifuging was essential if an autoradiogram with a low background level of silver grains and a sufficient concentration of bacteria for counting were to be obtained. Controls of dead bacteria were not labelled. The autoradiograms most suitable for counting were those prepared with $\mathrm{L}_{4}$ emulsion. Fig. $2(a)$ and $(b)$ shows autoradiograms of $\left[{ }^{3} \mathrm{H}\right]$ glucoselabelled bacteria from moribund leaves prepared for the LM. The high proportion of labelled bacteria in Fig. 2(a) can be compared with the lack of labelling of the control slide of bacteria fixed before labelling (Fig. $2 b$ ).

\section{High-resolution autoradiography}

Unsectioned bacteria could be resolved beneath an emulsion layer. An autoradiogram of $\left[{ }^{3} \mathrm{H}\right]$ glucose-labelled bacteria from moribund leaves is shown in Fig. $2(c)$. No labelled bacteria were seen on control grids of bacteria fixed before labelling.

\section{Comparison of percentages of labelled bacteria in LM and EM autoradiograms}

The percentages of labelled bacteria in LM and EM autoradiograms are shown in Table 2. Three counts of different areas of each of the LM autoradiograms were made and the mean percentage counts for each autoradiogram with their standard deviations are 

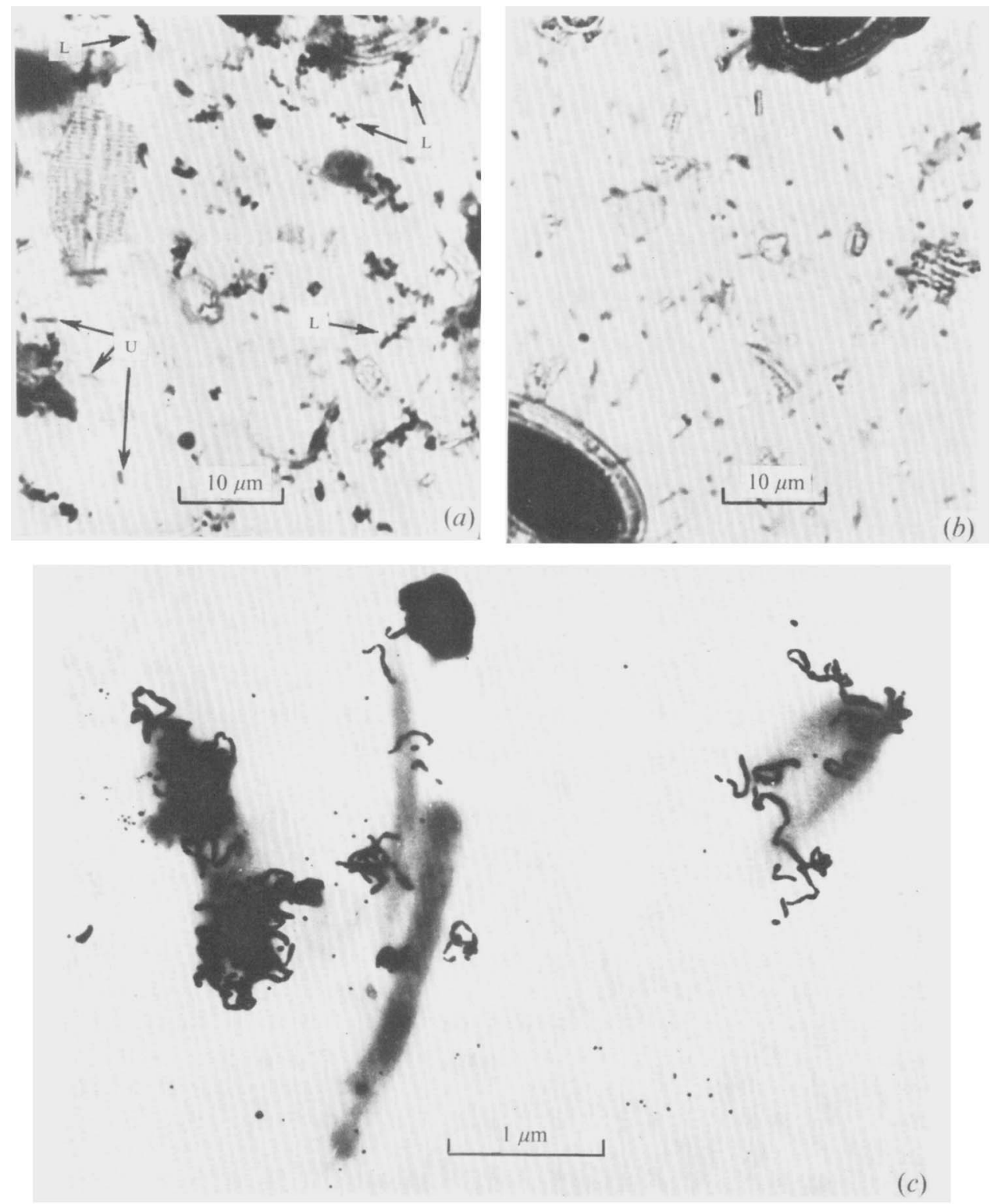

Fig. 2. Autoradiograms of $\left[{ }^{3} \mathrm{H}\right]$ glucose-labelled bacteria from moribund Elodea canadensis leaves. (a) LM autoradiogram showing labelled (L) and unlabelled (U) bacteria. (b) LM autoradiogram of sample fixed with glutaraldehyde before labelling; only unlabelled bacteria are visible. (c) High resolution autoradiogram exposed for 84 days, showing different degrees of labelling.

shown. The replicate counts of LM autoradiograms prepared from several batches of leaves suggested that there was greater variability between batches than in one sample. An analysis of variance of the $\left[{ }^{3} \mathrm{H}\right]$ thymidine data confirmed this. However, the distribution of labelled bacteria within each sample was very uniform, as shown by the small standard deviations of the counts from each autoradiogram.

Chi-square tests showed that there was no significant increase in counts of labelled 
Table 2. Percentage of labelled bacteria in $L M$ and EM autoradiograms

\begin{tabular}{|c|c|c|c|c|c|c|c|}
\hline \multirow[b]{3}{*}{ Sample } & \multirow{3}{*}{$\begin{array}{l}\text { Labelled } \\
\text { substrate }\end{array}$} & \multirow[b]{3}{*}{ Batch } & \multicolumn{5}{|c|}{$\begin{array}{l}\text { Bacteria labelled (\%) } \\
\text { after the following exposure periods (days) }\end{array}$} \\
\hline & & & \multicolumn{2}{|c|}{ LM } & \multicolumn{3}{|c|}{ EM } \\
\hline & & & 7 & 13 & 28 & 56 & 84 \\
\hline Pseudomonad 6w 5 & Glc & I & $92 \pm I$ & . & 80 & 83 & . \\
\hline $\begin{array}{l}\text { Bacteria from } \\
\text { Elodea leaves }\end{array}$ & Glc & $\begin{array}{l}\text { I } \\
\text { II } \\
\text { III } \\
\text { IV }\end{array}$ & $\cdot$ & $\begin{array}{c}7 \\
73 \pm 4 \\
83 \pm 2 \\
90 \pm 1\end{array}$ & $\begin{array}{l}\dot{.} \\
\dot{.}\end{array}$ & $\dot{.}$ & $\begin{array}{l}75 \\
. \\
. \\
.\end{array}$ \\
\hline $\begin{array}{l}\text { Bacteria from } \\
\text { Elodea leaves }\end{array}$ & $\mathrm{Td} \mathbf{r}$ & $\begin{array}{l}\text { I } \\
\text { II } \\
\text { III } \\
\text { IV } \\
\text { V }\end{array}$ & $\dot{.}$ & $\begin{array}{c}\cdot \\
60 \pm 2 \\
69 \pm 0.5 \\
72 \pm 2 \\
74 \pm 2\end{array}$ & $\begin{array}{l}65 \\
. \\
. \\
.\end{array}$ & $\begin{array}{l}70 \\
. \\
. \\
.\end{array}$ & $\begin{array}{l}72 \\
: \\
.\end{array}$ \\
\hline
\end{tabular}

Table 3. Bacterial populations on Elodea canadensis leaves of different ages, sampled in winter

\begin{tabular}{|c|c|c|c|c|c|c|}
\hline \multirow[b]{3}{*}{ Age of leaf } & \multirow{3}{*}{$\begin{array}{l}\text { Plate count } \\
\left(10^{-3} \times\right. \\
\text { no } / \mathrm{ml})\end{array}$} & \multirow{3}{*}{$\begin{array}{l}\text { Direct count } \\
\quad\left(\mathrm{IO}^{-3} \times\right. \\
\text { no. } / \mathrm{ml})\end{array}$} & \multirow{3}{*}{$\begin{array}{l}\text { Plate count } \\
\text { (as a percentage } \\
\text { of direct } \\
\text { count) }\end{array}$} & \multicolumn{3}{|c|}{ Autoradiography } \\
\hline & & & & \multirow[b]{2}{*}{ Batch } & \multicolumn{2}{|c|}{$\begin{array}{l}\text { Percentage of } \\
\text { bacteria labelled }\end{array}$} \\
\hline & & & & & {$\left[{ }^{3} \mathrm{H}\right]$ glucose } & {$\left[{ }^{3} \mathrm{H}\right]$ thymidine } \\
\hline Young & $0.59 \pm 0.14$ & $2 \cdot 29 \pm 1.09$ & $25 \cdot 8$ & $\begin{array}{l}\text { I, II } \\
\text { III }\end{array}$ & $17 \pm 3$ & 8 \\
\hline Mature & $I \cdot 37 \pm 0.24$ & $36 \cdot 22 \pm 16 \cdot 53$ & $3 \cdot 8$ & $\begin{array}{c}\text { I, II } \\
\text { III }\end{array}$ & $20 \pm 3$ & 10 \\
\hline Moribund & $I \cdot 45 \pm 0 \cdot 15$ & $I 44 \cdot 30 \pm 42 \cdot 30$ & $1 \cdot 0$ & $\begin{array}{l}\text { I } \\
\text { II }\end{array}$ & 45 & 27 \\
\hline
\end{tabular}

bacteria in the EM autoradiograms with exposure periods longer than 28 days, although further experiments would be required before any definite conclusion could be drawn on the exposure period needed to ensure that all bacteria, which have accumulated some label, form an autoradiogram.

The percentage of labelled pseudomonad $6 \mathrm{w} 5$ in the LM autoradiograms exposed for 7 days was significantly different from that in the EM autoradiogram exposed for 56 days. However, both the $\left[{ }^{3} \mathrm{H}\right]$ glucose and $\left[{ }^{3} \mathrm{H}\right]$ thymidine counts from the EM autoradiograms were within the range of counts obtained from the LM autoradiograms of different batches of leaves.

\section{Relationship between direct and indirect counts of bacteria and proportions of metabolizing bacteria determined by autoradiography}

The plate counts and direct counts gave very different estimates of the size of the bacterial populations on Elodea canadensis leaves (Table 3). According to the plate count data there were just over twice as many bacteria on the mature leaves as on the young leaves, but there was little further increase in the bacterial population as the leaves died. The results from the direct counts, however, showed that the mature leaves had about 16 times as many bacteria on them as the young leaves and that there was a further fourfold increase 
in the population when the leaves died. The percentage of the total population which was cultured decreased from $26 \%$ to I \% as the leaves aged.

Table 3 also shows the percentage of labelled bacteria in the different treatments. For the treatments where autoradiograms were prepared from replicate batches of leaves, three counts were made per autoradiogram. The data given are the average and standard deviation of the mean counts from the autoradiograms of the different batches. A single count was made of the other autoradiograms. The labelling showed that the proportions of bacteria taking up $\left[{ }^{3} \mathrm{H}\right]$ glucose and $\left[{ }^{3} \mathrm{H}\right]$ thymidine on young and mature leaves were similar, but that there was a marked increase when the leaves died. These results can be compared with the proportions of the bacterial populations on the different aged leaves, which were cultured. On the young leaves the percentage of the bacteria that was labelled with $\left[{ }^{3} \mathrm{H}\right]$ glucose was similar to the percentage that was cultured but there was an increasing difference as the leaves aged.

Although the percentages of metabolizing bacteria on the young and mature leaves were similar, the total number of metabolizing bacteria on the mature leaves would have been far greater because of the larger bacterial population present.

The percentage of bacteria taking up $\left[{ }^{3} \mathrm{H}\right]$ thymidine was always less than the percentage of $\left[{ }^{3} \mathrm{H}\right]$ glucose-labelled bacteria. There was a tendency for the ratio $\left[{ }^{3} \mathrm{H}\right]$ glucose: $\left[{ }^{3} \mathrm{H}\right]$ thymidine counts to decrease as the percentage of the population metabolizing $\left[{ }^{3} \mathrm{H}\right]$ glucose increased.

Much lower percentages of labelled bacteria were recorded from the autoradiograms from moribund leaves sampled in July (Table 3 ) than from leaves sampled in June (Table 2). This may have been related to the decrease in water temperature from $7 \cdot 6^{\circ} \mathrm{C}$ in June to $3.9^{\circ} \mathrm{C}$ in July.

\section{DISCUSSION}

In the pure-culture experiments, bacteria were initially cultured under favourable conditions so that when they were labelled nearly all the organisms would have been metabolizing. The aim was therefore to obtain autoradiograms in which nearly all the bacteria were labelled because there would then be maximum detection of labelling. The lack of detection of labelling with an isotope concentration of $\mathrm{I} \mu \mathrm{Ci} / \mathrm{ml}$ could have been because of the large number of metabolizing bacteria present. Each bacterium may have accumulated only a very small amount of isotope. Brock \& Brock (I968) emphasize the importance of having sufficient isotope incorporated into each bacterium to form an autoradiogram. The possibility that some label might have been lost from the cells after fixation with Lugol's iodine was not tested but Hobbie \& Wright (1965) mention that some loss may occur when this fixative is used. Apart from any such loss, both Lugol's iodine and glutaraldehyde were satisfactory fixatives, provided that they were washed from the sample before it came in contact with the emulsion.

The autoradiographic technique was developed to estimate the metabolic activity of a mixed population of bacteria. If counts of labelled bacteria are to be a direct measure of metabolic activity in situ, all bacteria metabolizing at the time of sampling must take up enough label to form an autoradiogram. Most heterotrophic bacteria are permeable to glucose and have enzymes to utilize it. Therefore, this carbohydrate was chosen to provide a general measure of the metabolic activity of the bacterial population. Neglecting those bacteria that cannot take up glucose will introduce only a small error, providing autotrophic bacteria do not make up a significant part of the population.

Uptake of thymidine and consequent incorporation into DNA provides an indication 
of the amount of cell division about to take place and thus a measure of the level of metabolic activity among the active bacteria. However, in the present study two of the six pure cultures of bacteria did not take up thymidine. Grivell \& Jackson (1968) have outlined possible mechanisms which could account for a lack of labelling of DNA when organisms are incubated with radioactive thymidine. No attempt was made in the present study to determine the mechanism involved, but the possibility of such a lack of uptake in an unknown proportion of bacteria from a mixed population in the field severely limits interpretation of thymidine-uptake data. It is also possible that some of the label could have been in parts of the bacterium other than DNA as no biochemical extraction procedures were carried out to ensure that only those bacteria where $\left[{ }^{3} \mathrm{H}\right]$ thymidine was incorporated into DNA produced an autoradiogram.

Because $\mathrm{L}_{4}$ emulsion is more sensitive to $\beta$-radiation than $\mathrm{K}_{2}$, the incubation and exposure periods and isotope concentrations determined with $\mathrm{K}_{2}$ emulsion will be satisfactory for $\mathrm{L}_{4}$ emulsion, although these conditions may not be the minimum ones for detecting metabolizing bacteria with $\mathrm{L}_{4}$ emulsion. $\mathrm{L}_{4}$ emulsion was more suitable than $\mathrm{K}_{2}$ for the LM autoradiograms of field material. The smaller grain size of this emulsion meant that more of a bacterium was visible around the silver grains. L4 emulsion had a longer shelf life than $\mathrm{K}_{2}$ and the lower background level of grains of $\mathrm{L}_{4}$ was useful for samples where the percentage of labelled cells was low. The formation of several silver grains in the $\mathrm{L}_{4}$ emulsion from one $\beta$-emission was not a problem as individual grains were not counted. Bacteria were recorded only as labelled or unlabelled.

A critical factor in the looping method for applying emulsion to EM grids was the fluidity of the emulsion. If emulsion was applied before it had gelled it 'slid off' the unsectioned bacteria.

The comparison of counts of labelled bacteria from LM and EM autoradiograms of pseudomonad $6 \mathrm{w} 5$ suggested that if a large proportion of bacteria were labelled and were clumped, the count from the LM autoradiogram might be underestimating unlabelled organisms. The data from the autoradiograms of bacteria from moribund Elodea canadensis leaves indicated that to compare the counts of labelled bacteria in EM and LM autoradiograms, a single batch of leaves would have to be used for comparable autoradiograms. Nevertheless, the data available suggested that valid counts of labelled bacteria from a mixed population could be obtained from LM autoradiograms provided the organisms were not clumped.

High-resolution autoradiography has advantages over LM autoradiography when bacteria are lightly labelled as grains are more easily distinguishable. On the other hand, preparation of material for the EM takes longer and the autoradiograms cannot be examined for several months.

The study of bacteria on Elodea canadensis leaves of different ages suggested that for young leaves the plate count might be providing a realistic estimate of the active bacterial population. The percentage of bacteria labelled with $\left[{ }^{3} \mathrm{H}\right]$ glucose and the percentage of the total population which was estimated by the plate method were similar. However, on the mature and moribund leaves, although 20 to $45 \%$ of the populations formed autoradiograms when labelled with $\left[{ }^{3} \mathrm{H}\right]$ glucose, less than $4 \%$ of the total populations were included in the plate counts. As larger proportions of bacteria were labelled on these leaves than on the young leaves, the possibility that there was an increasing proportion of dead bacteria on the mature and moribund leaves was discounted. One possible explanation which was not tested was that there was an inhibitor associated with the older leaves which was released when leaves were comminuted before plating. 
The experiment with leaves of different ages emphasized the importance of determining the absolute number of metabolizing bacteria as well as the proportion of the population metabolizing. The data from the young and mature leaves illustrated that a count of the percentage of labelled bacteria could fail to show differences in the relative size of the active populations.

The thymidine-uptake data suggested, within the limitations discussed previously, that with increasing age of leaf more of the bacteria were dividing and thus growing more rapidly.

Autoradiography can be a valuable technique in the study of the activity of bacteria in situ. Methods of preparing autoradiograms of bacteria from water and mud sampled from a lake have also been developed (Ramsay, 1972). However, although quantitative data can be obtained from autoradiograms, interpretation of such data is often difficult. One problem is the significance of negative results which may be inherent in the technique rather than an indication that bacteria were not metabolizing in situ. For this reason further basic studies on the detection of uptake of labelled compounds by pure cultures of bacteria, by means of autoradiography, are needed. Nevertheless, provided conditions of autoradiography are defined carefully so that the validity of interpretations can be assessed, this technique can be extremely useful in estimating the metabolic activity of bacteria in their natural environments.

This work was supported in part by a grant from the University of Canterbury. I am grateful to Dr J. S. Waid and Dr J. D. Allen for helpful discussions and for comments on the manuscript.

\section{REFERENCES}

Anderson, R. L. \& Ordal, E. J. (I96I). Cytophaga succinicans sp.n., a facultatively anaerobic, aquatic myxobacterium. Journal of Bacteriology 8x, $130-138$.

BÉlanger, L. F. (I96I). Staining processed radioautographs. Stain Technology 36, 31 3-3I 7 .

Brock, M. L. \& Brock, T. D. (1968). The application of micro-autoradiographic techniques to ecological studies. Mitteilungen der Internationalen Vereinigung für theoretische und angewandte Limnologie $\mathbf{1 5}, \mathbf{I}-29$.

Caro, L. G. \& van Tubergen, R. P. (1962). High resolution autoradiography. I. Methods. Journal of Cell Biology 15, 173-188.

Grivell, A. R. \& JACKSON, J. F. (I968). Thymidine kinase: evidence for its absence from Neurospora crassa and some other micro-organisms, and the relevance of this to the specific labelling of deoxyribonucleic acid. Journal of General Microbiology 54, 307-317.

Gude, W. D. (1968). In Autoradiographic Techniques, p. 29. Englewood Cliffs, New Jersey: Prentice-Hall.

HoBbIE, J. E. \& WRIGHT, R. T. (1965). Bioassay with bacterial uptake kinetics: glucose in freshwater. Limnology and Oceanography ro, $47 \mathrm{I}-474$.

Horne, R. W. (1965). Negative staining methods. In Techniques for Electron Microscopy, pp. 328-355. Edited by D. H. Kay. Oxford: Blackwell.

JANNASCH, H. W. (I965). Biological significance of bacterial counts in aquatic environments. Collected Reprints from the Woods Hole Oceanographic Institution no. 1490.

Munro, A. L. S. \& Brock, T. D. (1968). Distinction between bacterial and algal utilization of soluble substances in the sea. Journal of General Microbiology 51, 35-42.

Paerl, H. W. \& Goldman, C. R. (I972). Heterotrophic assays in the detection of water masses at Lake Tahoe, California. Limnology and Oceanography 17, 145-148.

RAmSAY, A. J. (1972). Studies on the microorganisms of a freshwater lake. Ph.D. thesis, University of Canterbury, New Zealand.

Rogers, A. W. (I967). In Techniques of Autoradiography, p. 263. Amsterdam: Elsevier.

Waid, J. S., Preston, K. J. \& Harris, P. J. (I971). A method to detect metabolically-active microorganisms in leaf litter habitats. Soil Biology and Biochemistry 3, 235-24I. 